\title{
A Preface to the Issue on Derek Walcott's National and Global Theatre
}

\section{Chihoko Matsuda}

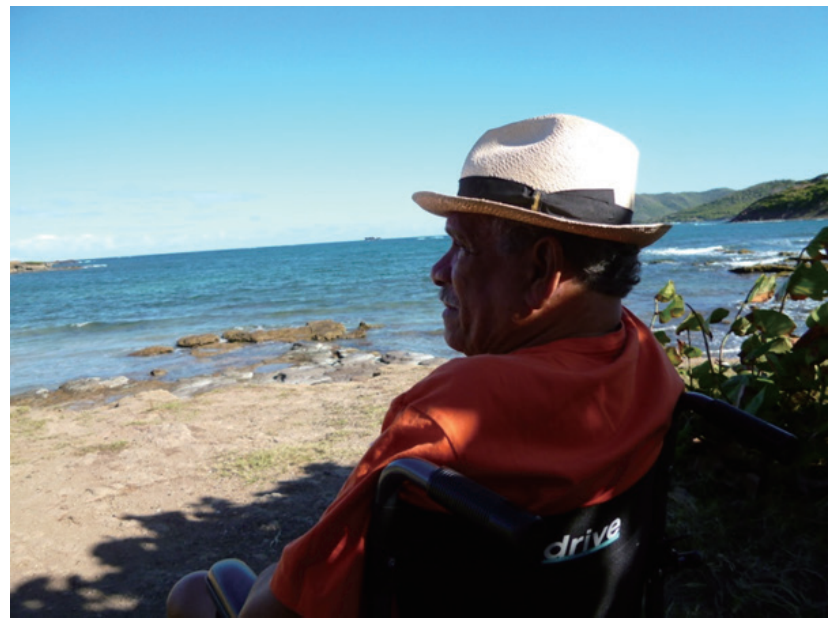

Walcott gazing at the Atlantic on the Cas-en-Bas beach, January 2013

Derek Walcott (born on the island of St. Lucia, 1930- ) is undoubtedly one of the most eminent poets and men of theatre writing in English today. It was poetry rather than theatre that earned him international acclaim as the Nobel Prize Foundation honoured him 'for a poetic oeuvre of great luminosity, sustained by a historical vision, the outcome of a multicultural commitment.'

Yet, for six decades from the 1950s to 2014, Walcott has been at the forefront of theatre as a playwright, stage director, and founder of theatre companies. As the standard-bearer of the Caribbean national theatre movements, he wrote and directed many theatrical masterpieces, full of local character and vernacularism; many of his works also attract audiences all over the world, including the US, the UK, and Canada, for their honest and powerful portrayal of universal themes such as life, beauty, nature, art, history, economy, society and politics.

Compared with other literary genres such as poetry, novel, and music, theatre and drama are characterised by publicness as theatre and drama scholars Wilmesh and Bigsby put it, '[t]he theatre, the most public of the arts, has always been a sensitive gauge of social pressures and public issues'.(1) Because of these innate characteristics of the genre, theatrical works obviously reflect the facts of real life as well as the historical, social, cultural and political contexts of a developing and changing society. In this sense, Walcott as a man of theatre must be discussed from both viewpoints of theatre studies and drama studies. As theatre and drama is a composite art form, analysing Walcott's written texts is just a part of efforts to understand this long-time esteemed man of theatre who devoted himself to living theatre not only as a dramatist, but stage director, founder of theatre companies, and

(1) WILMESH, Don B., and BIGSBY, Christopher, eds. (1998). The Cambridge History of American Theatre, Vol. 3, Cambridge, Cambridge University Press, p. xv. 
drama critic.

As a man of theatre, Walcott has to date been researched by a modest number of scholars. In his The Theatrical into Theatre: Study of Drama and Theatre in the English Speaking Caribbean (1982), Kole Omotoso discusses Walcott's theatrical activities and work as a leading British Caribbean artist within the historical context of the region's theatre and drama. When Walcott's international fame became unassailable after he won the 1992 Nobel Prize in Literature, remarkable studies on his contribution to theatre and drama emerged. Literary scholar Laurence Breiner, one of the contributors to this issue, published a chapter on Walcott's 'Early Drama' in The Art of Derek Walcott (1992), edited by Stewart Brown. In 1995, Bruce King published a biographical volume on Walcott's theatrical activities, Derek Walcott and West Indian Drama, while John Thieme devoted a chapter to introducing Walcott as a Creole dramatist in his authoritative introduction to the playwright, Derek Walcott (1999).

As the 21st century began, considerably more detailed studies came out. In 2008, Viola Julia Davis wrote Derek Walcott: Dramatist-Creole Drama for Creole Acting, in which she focuses on the Creoleness demonstrated in Walcott's 'drama that bears the special marks of its Caribbean origin and setting and embodies the hybrid nature of Caribbean history, culture and personality' (p. 1). Most recently, in December 2013, two great volumes entitled Derek Walcott, the Journeyman Years: Culture, Society, Literature, and Art; Occasional Prose 1957-1974 appeared from the publisher Rodopi. Editors Gordon Collier (Volume 1 and 2) and Christopher Balme (Volume 2) collected a large number of Walcott's journalistic writings from the 1950s through the early 1970s, selected from various sources such as Guardian (Trinidad and Tobago), Public Opinion (Jamaica), and The Voice of St. Lucia (St. Lucia).

In addition to primary and secondary sources previously collected and published, this issue of Comparative Theater Review on Derek Walcott as an artist working in theatre, will surely fuel future studies on this distinguished Caribbean artist's work.

This issue includes the latest interview with Walcott, who was just turning 83 at the time it was conducted, on Caribbean National Theatre as well as a variety of academic papers on Walcott's theatrical work and career, written from unique viewpoints. Among them are drama studies which focus on specific written texts and papers which belong to the field of theatre studies and include fieldwork. The keywords for contributors' studies range from colonialism, post-colonialism, cosmopolitanism, and globalism to cultural anthropology.

Breiner's paper studies influences of Japanese performing arts and films on Walcott's aesthetics and early theatrical works. Although Walcott himself often referred to his attachment to the Japanese arts in certain interviews and essays, little attention has been paid to this subject academically. Matsuda's paper gives a socio-cultural background of Walcott's theatrical career and ideas of Caribbean theatre in terms of 'a national theatre', which has been hindered by the extreme influence of neocolonialistic tourism.

Two papers are textual analyses of Walcott's plays. Sakuma revaluates Walcott as a cosmopolitan dramatist in her paper on his 1992 opera, Walker, whose main plot deeply relates to the history of the abolition of slavery in the United States. Grant discusses the Caribbean tourist industry as an example of neocolonialism, as represented in Viva Detroit (1990). Both plays have rarely been discussed in former studies. Especially Viva Detroit remains so scarce that copies remain available 
only in certain libraries, including the Thomas Fisher Rare Book Library at the University of Toronto in Canada. Although Walcott is a prolific playwright, not all his works have ever been published, or some works are out of print. The inaccessibility of this eminent contemporary playwright's primary sources all the more emphasises a characteristic unique to the genre of theatre and drama: that is, the fun and fascination of a theatrical work do not lie only in the written text but should be understood as a form of composite art.

The papers that appear in this issue thus present the various aspects of Walcott's identity as an international giant in theatre. In effect, his theatrical activities as well as his plays are all concerned with the social, political, cultural, and historical environment of the Caribbean region; nevertheless, his plays and productions increasingly receive high academic regard internationally. An examination of this quality of Walcott's approach to theatre, which takes into account his genre's uniqueness and his extensive, long-term engagement with it, in addition to his theatrical texts and ideas on theatre and drama, is indeed a first for an academic journal.

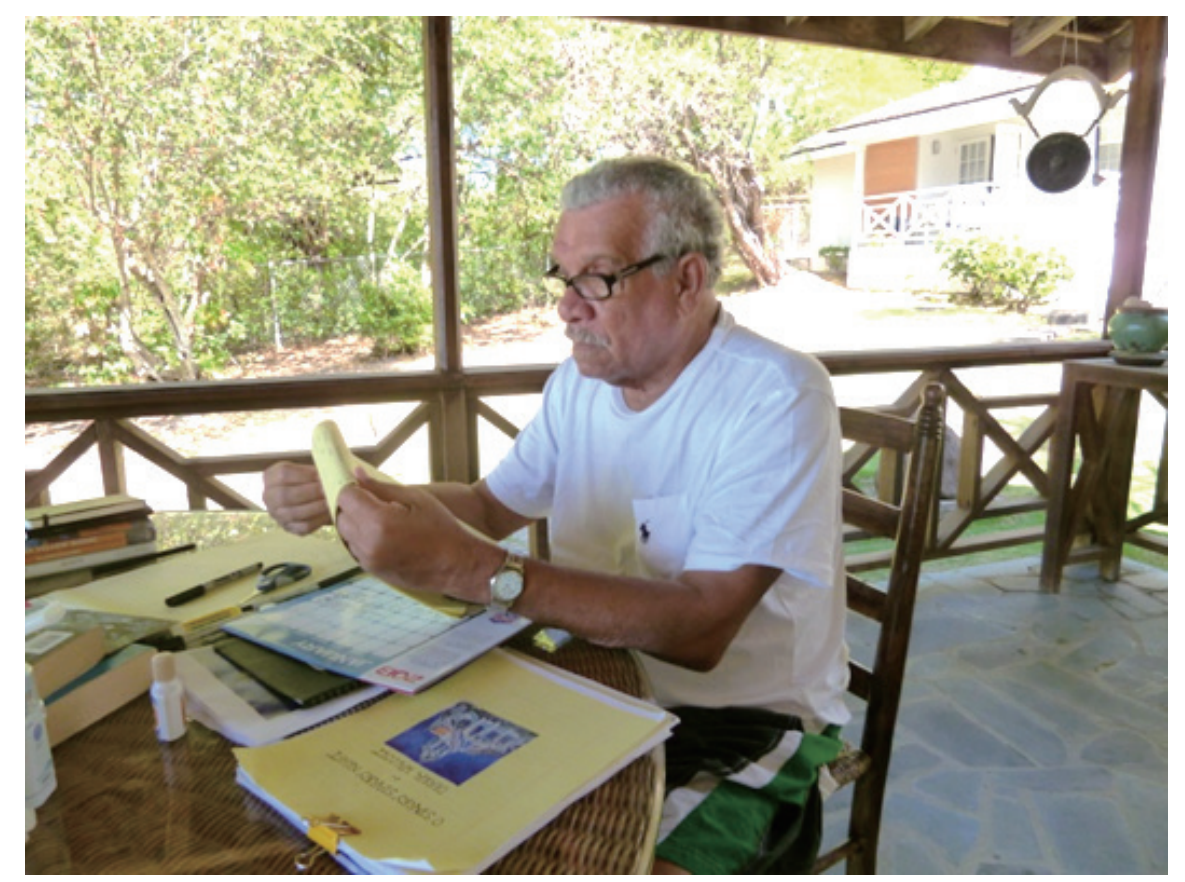

In the Morning: Walcott works on the porch at home 